\title{
SIGNIFICANCE OF COOPERATION FOR THE DEVELOPMENT OF ORGANIC AGRICULTURE
}

\author{
Olha Alieksieieva ${ }^{1}$
}

\begin{abstract}
The purpose of the article is to study the impact of the basic principles and benefits of the development of cooperative movement on the development of organic agricultural production, as well as to determine the role of cooperation in the development of organic entrepreneurship. Methodology. The author has used the methods of analysis and synthesis, the method of statistical grouping and comparison, induction and deduction, structural and functional approach to solve the problems and achieve the goals. The study is based on the comparative analysis and synthesis of scientific literature. Results. Organic food is increasing in popularity. The growing demand is mainly attributable to consumer concerns about negative implications of conventional agriculture for human health and the environment. Organic agriculture has a great potential to neutralize a negative impact of agricultural intensification on the environment. The article describes the concept and analyzes the current state of cooperation in agriculture. It is found that during the period under the research, the number of registered cooperatives has increased by almost $45 \%$. The concepts of organic agriculture and organic production are clarified. The dynamics of agricultural lands engaged in organic production and the number of certified organic farms in Ukraine are studied. It is indicated that the consumption of organic products in Ukraine is much lower than in the European countries and the United States. The advantages of introducing a cooperative movement in the field of organic agriculture are identified. Being part of a cooperative helps small farms to be able to produce enough to generate profits and ensure their substance, which is an opportunity to compete with larger companies. Risks arising in the process of establishing organic cooperatives are outlined considering the international experience. It is concluded that efficient organic farming cooperatives can support local and export markets, stimulate production efficiency and promote local logistics. Practical implications. The advantages of consolidation of enterprises and entrepreneurs in the field of organic agriculture on the basis of cooperation can be used for the development of state programs to support the cooperative movement in organic farming. Value/originality. Views on the organization of production, processing and logistics activities of organic agricultural producers through the introduction of cooperatives have been expanded.
\end{abstract}

Key words: organic agriculture, cooperation, sustainable development, organic entrepreneurship, organic market dynamics, organic cooperative.

JEL Classification: Q12, Q13, Q15

\section{Introduction}

Intensification of farming has resulted in a negative impact on the environment, depletion of natural resources and freezing out of a large number of small and medium-sized producers. Organic agriculture has a great potential to improve these negative trends.

It is possible to promote the extension of organic entrepreneurship, while creating real competition for powerful agricultural producers through cooperation, which enables to join efforts in order to achieve better results. The global cooperative experience convincingly shows that cooperation is not only a type of production or a form of economic activity, but it is an economically determined ideology of survival of a producer in today's tough economic and political conditions, including given the complexity of competition with large corporations and agricultural holdings.

This issue is quite relevant for the organic industry, asin recentyears more and more small producershave tended not to export their products, but to sell them in the domestic market while meeting the demand of the population for high quality food. In addition,

Corresponding author:

${ }^{1}$ NSC "Institute of Agrarian Economics”, Ukraine.

E-mail: olga_alieksieieva@ukr.net 
in the Ukrainian realities of economic development, insufficient attention is paid to the possibilities of the influence of cooperative movement on the development of organic agriculture.

\section{Literature review}

A great contribution to the study of theoretical and methodological principles of the institutional support for the development of business formations and cooperative relations in agriculture has been made by the scientists of the National Research Center "Institute of Agrarian Economics" (Lupenko et al., 2016). The issues of greening the systems of enterprise management, production of eco-friendly goods and the role of small and medium-sized business in organic entrepreneurship are examined by Zhelibo, Hatska, \& Murovana (2020). The prospects for the development of small organic business in rural areas have been outlined by Korobka (2019). Khodakivska \& Shpykuliak (2017) emphasize the need to introduce a "green" course of the economy in agriculture in the context of extending European integration processes. Khodakivska, Shpykuliak \& Suprun (2017) aim to solve the problems of ecofriendly development, as well as to clarify the role and importance of institutions in the organizational support of sustainable development of the agrarian sector. Issues of the development of organic farming cooperatives in the context of the international and domestic experience are studied by Bezus \& Bilotkach (2020). The importance of "green" cooperatives for the formation of the institutional mechanism of the development of alternative energy in the agrarian sector is outlined by Shpykuliak \& Bilokinna (2019).

In the foreign scientific literature, the conclusions made by the scientists on the role of organic agriculture for the global sustainable development differ considerably. Some of them consider organic agriculture to be inefficient and largely driven by ideology (Connor \& Mi' nguez, 2012; Lotter, 2015; Trewavas, 2001), while others argue that organic agriculture has a great potential for eco-friendly feeding of the world population (Badgley et al., 2007; Reganold \& Wachter, 2016; Kristiansen, Taji \& Reganold, 2006).

\section{The concept and current state of cooperation}

Cooperation is one of the fundamental concepts of the world economics. Cooperatives emerged under the influence of socio-ethical ideas and were a new form of organization of production and social protection of their members.

Ukrainian cooperation has a 145-year history. The first cooperative society was established in 1866 in Kharkiv. The specificity of cooperatives as socio-economic socially oriented and democratic organizations determined a special role of the human factor. Its success was explained by the fact that among the founders and popularizers of the cooperative idea were the most authoritative leaders of the Ukrainian community of that time, namely V. Antonovych, M. Drahomanov, S. Podolynskyi, S. Kachala, D. Taniachkevych, M. Ballin, M. Levitskyi and others (Helei, 1999).

In the world practice, there has widely spread cooperation in the areas providing services to the agricultural producer in organizing such processes as sales and processing of manufactured products, logistics and other types of production services through the establishment of agricultural service cooperatives.

From 40 to $90 \%$ of agricultural products are sold through a system of cooperatives owned directly by agricultural producers. Thus, in Western countries, cooperatives provide up to $50 \%$ of the volume of production of food industry as well as mixed feeds. Cooperatives supply a significant part of fuels and lubricants (44\% in the USA and $40 \%$ in Finland). More than $60 \%$ of marketable products of the agricultural sector are sold through cooperatives in the EU, $80 \%$ in the Scandinavian countries, $90 \%$ in Japan and China (Lupenko et al., 2016, p. 282).

Availability of a large number of different views concerning the definition of the essence of cooperation is explained by its objectives, position and role in the development of society. It cannot be argued that in the world theory or practice there has already been formed a comprehensive idea of the real nature of cooperation, its logical, theoretical, and methodological principles (Lupenko et al., 2016, p. 281).

In Ukraine, formation of a cooperative movement is regulated by the Laws of Ukraine "On Cooperation" dated July 10,2003 (Pro kooperatsiiu, 2003) and "On Agricultural Cooperation" dated July 17, 1997 (Pro silskohospodarsku kooperatsiiu, 1997). These documents stipulate that an agricultural cooperation is a system of agricultural cooperatives and their associations formed to meet economic, social and other needs of the cooperative members. In particular, there has been distinguished an agricultural production 


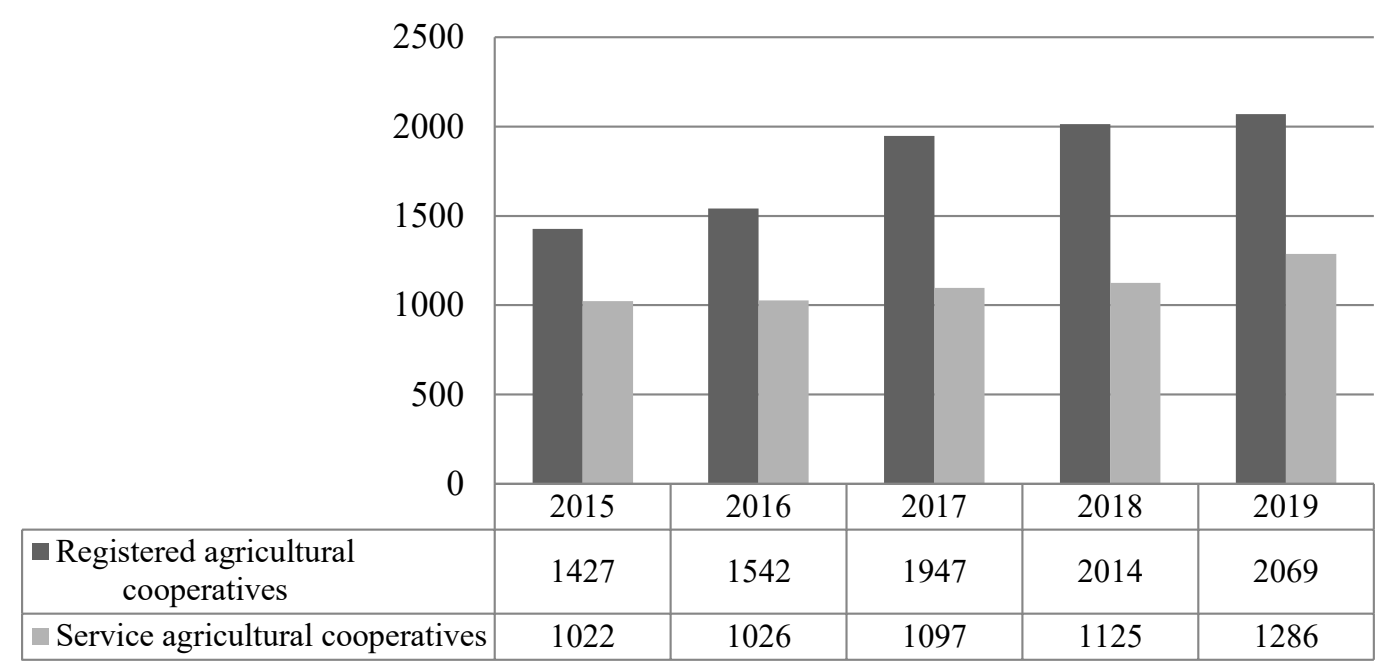

Figure 1. Dynamics of changes in the number of agricultural cooperatives in Ukraine in 2015-2019

cooperative formed through a merger of individuals who are producers of agricultural products, as well as an agricultural service cooperative formed through a merger of individuals and/or legal entities that are producers of agricultural products for servicing aimed at reducing costs and/or increase of the income of the members of this cooperative during their agricultural activities and protecting their economic interests (Pro silskohospodarsku kooperatsiiu, 1997).

According to the Information and Analytical Portal of the Agro-Industrial Complex of Ukraine, as of January 1,2019, there were 1,286 agricultural service cooperatives in Ukraine. Over the last 5 years, their number has increased by $26 \%$. There has also been observed a positive tendency in the number of registered agricultural cooperatives. Thus, during the period under research, the number of registered agricultural cooperatives has increased by almost $45 \%$ (Figure 1 ).

Despite a low level of development of agricultural cooperation in the market of organic products, it has significant prospects. Cooperation provides opportunities for small producers to compete in the domestic and foreign markets due to creation of an adequate procurement and marketing material base, consistency in the production of homogeneous products, formation of product batches, systematic supply of products throughout the year, development of primary and in-depth processing of agricultural products. These benefits of the cooperative affect the income of producers of organic products - members of the cooperative and contribute to the increase of local budgets.

\section{The concept and current state of organic agriculture}

The organic market of Ukraine is constantly evolving. Due to the size of the country $\left(603,600 \mathrm{~km}^{2}\right.$, including 42.7 million hectares of agricultural land), geographical location, proximity to potential international buyers and extensive fertile black soils, Ukraine has favorable conditions for organic agriculture.

According to the Organics International (IFOAM), organic agriculture is a production system that supports the health of soils, ecosystems and people. It depends on environmental processes, biodiversity and natural cycles specific to local conditions, while avoiding the use of harmful resources that cause adverse effects.

The Law of Ukraine "On the Basic Principles and Requirements for Organic Production, Circulation and Labeling of Organic Products" (2018) stipulates that organic production is a certified activity related to the production of agricultural products (in particular, all stages of the technological process, namely primary production (including harvesting), preparation, treatment, mixing and related procedures, filling, packaging, processing, recovery and other changes in the state of production), which is carried out in compliance with the legislation in the field of organic production, circulation and labeling of organic products.

In 2019, 597 certified organic enterprises (including 294 agricultural enterprises) were engaged in organic production, the largest share of which were small enterprises, with a total area of over 300 thousand hectares, which was $0.7 \%$ of 


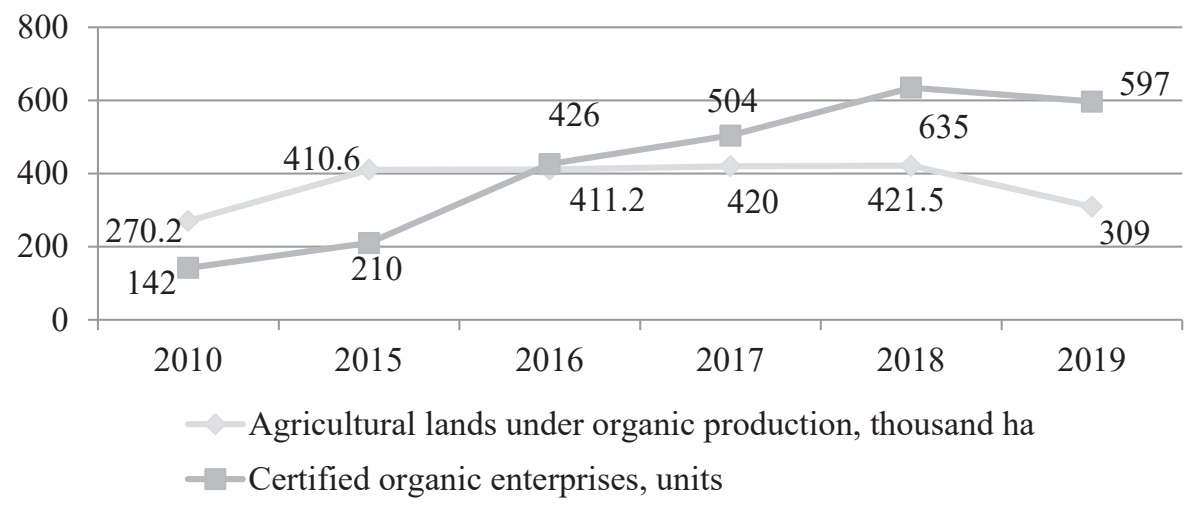

Figure 2. Dynamics of agricultural lands under organic production
and the number of certified organic farms in Ukraine

Source: formed according to (Ukrainian Agribusiness: Infographic Report 2019/2020; Organic Market in Ukraine, 2020)

the total area of agricultural lands. In recent years, the area of organic production in Ukraine has grown significantly, which has made it possible to enter top 20 of countries in terms of the area in the world, as well as to rank $11^{\text {th }}$ in Europe (Figure 2). At the same time, almost half of organic lands of Ukraine are under cereals (48.1\%), oilseeds (16\%), legumes $(4.6 \%)$, vegetables $(2 \%)$, fruits $(0.6 \%)$, and grapes $(0.1 \%)$. Hence, the main exported organic products are cereals, oilseeds and legumes, wild berries, mushrooms, nuts and medicinal plants (Vnutrishnii rynok orhanichnoi produktsii Ukrainy, eksport ta import za 2019 rik).

Most organic operators in Ukraine are certified according to the EU organic standard, which is equivalent to Commission Regulations 834/2007 and $889 / 2008$, which are applied both to the export of organic products and to the domestic market. Ukrainian organic operators are also often certified under the US National Organic Program (NOP) and/or the Canada Organic Regime (COR). Other organic standards used in Ukraine are as follows: Bio Suisse (Switzerland), Naturland and Bioland (both Germany), JAS (Japan) and KRAV (Sweden).

The main countries importing Ukrainian organic products are the Netherlands, Germany, Great Britain, France, Italy, Poland, Austria, Romania, Lithuania, Denmark, Switzerland, and the USA. However, the consumption of organic products in Ukraine is much lower than in the European countries and the United States, it comprises 0.5 EUR per person, while in the EU it is 40 EUR per person. In 2019, 7,350 tons of organic products of about 575 million UAH worth were sold on the domestic market. Trade of organic food and organic public catering are concentrated mainly in the capital and cities with the population of over million people or industrial centers. Total export of Ukrainian organic products in 2019 amounted to 189 million USD (Vnutrishnii rynok orhanichnoi produktsii Ukrainy, eksport ta import za 2019 rik).

\section{Benefits and problems of cooperation development in organic agriculture}

Due to the establishment of multifunctional cooperatives, agricultural producers can significantly improve their market position, gain direct access to consumers and manufacturers of material and technical means or strengthen their market position, which will allow them to battle for their interests more effectively with various commercial firms and processing enterprises.

Cooperation and integration in the agrarian sector of the economy create the benefits of such forms of economic activity compared to others due to accumulation of labor, financial and other resources; reduction of the time period required for production; saving due to the scale; synergistic effect; opportunities for access to new knowledge (technology, machinery, organization of production, management, marketing, etc.); wider dissemination of knowledge and information; optimization of information flows; greater opportunities for social development of the region; creation of new jobs; increase in revenues to the local budget; provision of better conditions for combining personal interests of their members with the interests of all participants of the production process; protection of members of the association from monopolistic manifestations of suppliers, sales, banking, and other structures. 
Cooperation provides opportunities for small producers to compete in the domestic and foreign markets by creating an appropriate procurement and marketing base as well as a material and technical base, consistency in the production of homogeneous products, formation of product batches, ensuring systematic supply of products throughout the year, development of primary and in-depth processing of agricultural products.

The study of the international experience of organic farming cooperatives has led to the conclusion that the path to success in this type of agribusiness has not been easy. According to Bezus \& Bilotkach (2018), there are a number of risks, in particular:

- the risk of dissatisfaction with the expectations of all members of the cooperative;

- the risk of suboptimal calculation of project implementation time;

- the risk not to compete with large agricultural producers;

- the risk of violating the technology of organic cultivation and processing of products during crisis periods, etc.

The world practice proves that financial risks and losses during the transition of agricultural producers to organic farming methods can be reduced by the formation of cooperatives.

Insufficient systemic support for operating agricultural cooperatives and associations limits the ability to share resources and production facilities (e.g., equipment, agricultural resources and subsidies). Other challenges for the organic sector of agriculture include instability in the supply chain of organic products, lack of cooperation between producers and coordination in logistics, as well as low level of interest.

In order to obtain a reliable assessment of the organic sector, it would be appropriate to organize the collection and processing of information concerning its operators at the national level. In our opinion, in order to deepen the analysis of the tendencies of the development of organic agriculture in Ukraine, it is advisable not only to keep a register of relevant operators, but also to oblige the relevant Ministry unit responsible for this sector to collect and disseminate more detailed free of charge information on organic operators in accordance with the EU practice.
Eurostat distinguishes the following indicators: the number of organic operators according to the status of their registration process; areas under organic farming in terms of crops; volumes of organic production by the types of plants; organic livestock herd; volumes of production of organic livestock products by the species; number of processors of organic products by their type.

\section{Conclusions}

Therefore, an organic cooperative is essentially a community of producers who voluntarily cooperate with each other being both its owners and employees in order to achieve a greater economic effect, especially from the synergy of joint activities. The fact that each member of the cooperative is an entrepreneur who acts for his or her own benefit, determines high efficiency of cooperation. The essence of cooperation as an economic phenomenon is based on the economic relationships between the partners in order to achieve a common goal at the lowest possible inputs of resources on the basis of mutual benefit for all participants of cooperation.

In the developed countries, cooperatives operating in the field of sales have become the most widespread. In different countries, cooperative structures have different share in agribusiness, but for sure, it is a powerful economic force aimed at developing the agri-food sector.

Cooperation as a basis for the formation of the organic market will help to ensure efficient production and eliminate conflicts between direct production, processing, food industry, trade, and consumers. Having observed the state's interest in the development of the natural food market, business will be more willing to invest in this industry. This will lead to an increase in jobs in rural areas.

Effective organic farming cooperatives can support local and export markets, stimulate production efficiency, and facilitate local logistics. This support can be provided in the form of information exchange concerning local and export markets and facilitation of the access to the necessary agricultural resources, as well as through fiscal mechanisms such as grants and loans to cooperatives of organic farmers.

\section{References:}

Badgley, C., Moghtader, J., Quintero, E., Zakem, E., Chappell, MJ., et al. (2007). Organic agriculture and the global food supply. Renew. Agric. Food Syst., vol. 22, pp. 86-108. 
Bezus, R., \& Bilotkach, I. (2018). Development of Organic Farmers' Cooperatives: the USA, the EU, and Ukraine. Baltic Journal of Economic Studies, vol. 4(2), pp. 24-31. Retrieved December 16, 2020 from: https://doi.org/10.30525/2256-0742/2018-4-2-24-31

Connor D. J., \& Mi'nguez, M. I. (2012). Evolution not revolution of farming systems will best feed and green the world. Global Food Security, 1, 106-113.

Helei, S. (Ed.) Ukrainski kooperatory. Istorychni narysy [Ukrainian Cooperators. Historical Essays] (1999). Book 1. Lviv: "Ukooposvita" of Lviv Commercial Academy, 456 p.

Khodakivska, O. V., Shpykuliak O. H., \& Suprun O. M. (2017). Instytuty "zelenoi ekonomiky" u zabezpechenni staloho rozvytku ahrosektoru [Institutes of "green economy" in ensuring sustainable development of the agricultural sector]. Biznes-Inform [Business Inform], vol. 7, pp. 13-18.

Khodakivska, O. B., \& Shpykuliak, O. H. (2017). Perspektyvy zaprovadzhennia "zelenoho" kursu ekonomiky u silske hospodarstvo Ukrainy $\mathrm{v}$ umovakh pohlyblennia yevrointehratsiinykh protsesiv [Perspectives of introduction of "green" course of economy in the agriculture of Ukraine under the conditions of intensification of the European integration processes]. Formuvannia ta rozvytok cuchasnoi modeli bioekonomichnoi systemy na silskykh terytoriiakh [Formation and Development of a Modern Model of the Bioeconomic System in Rural Areas], vol. 3, pp. 31-34.

Korobka, S. V. (2019). Orhanichne vyrobnytstvo: novi mozhlyvosti dlia maloho pidpryiemnytstva na silskykh terytoriiakh [Organic production: new opportunities for small business in rural areas]. Vcheni zapysky TNU imeni V.I. Vernadskoho. Seriia: Ekonomika i upravlinnia [Scientific Bulletin of TNU named after V.I. Vernadskyi. Series: Economics and Management], vol. 230(69), pp. 40-44.

Kristiansen, P., Taji, A., \& Reganold, J. P. (2006). Organic agriculture: Opportunities and challenges. Retrieved December 16, 2020 from: https://www.researchgate.net/publication/254757249_Organic _ agriculture_Opportunities_and_challenges

Lotter, D. (2015). Facing food insecurity in Africa: why, after 30 years of work in organic agriculture, I am promoting the use of synthetic fertilizers and herbicides in small-scale staple crop production. Agric. Hum. Values, vol. 32, pp. 111-118.

Lupenko, Y. O., Malik, M. J., Zaiats, V. M., et al. (2016). Rozvytok pidpryiemnytstva i kooperatsii: instytutsionalnyi aspekt: monohrafiia [Development of Entrepreneurship and Cooperation: Institutional Aspect: monograph]. Kyiv: NSC "IAE”, 432 p.

Orhanichnyi rynok v Ukraini: informatsiinyi biuleten vid 12.02 .2020 r. [Organic Market in Ukraine newsletter of February 12, 2020]. Retrieved December 16, 2020 from: https://organicinfo.ua/ wp-content/uploads/2020/02/UAOrganic_fact_sheet_2020-UA-1.pdf

Pro kooperatsiiu: Zakon Ukrainy vid 10.07.2003 r. № 1087-15 [On Cooperation: Law of Ukraine of July 10, 2003 No 1087-15]. Retrieved December 16, 2020 from: http://zakon4.rada.gov.ua/laws/show/1087-15

Pro osnovni pryntsypy ta vymohy do orhanichnoho vyrobnytstva, obihu ta markuvannia orhanichnoi produktsii: Zakon Ukrainy № 2496-VIII [On the Basic Principles and Requirements for Organic Production, Circulation and Labeling of Organic Products: Law of Ukraine No 2496-VIII]. Vidomosti Verkhovnoi Rady vid 10 lypnia 2018 roku [Information of the Verkhovna Rada of July 10, 2018]. Retrieved from: https://zakon.rada.gov.ua/laws/show/2496-19\#Text

Pro silskohospodarsku kooperatsiiu: Zakon Ukrainy vid 17.07.1997 r. № 469/97-VR [On Agricultural Cooperation: Law of Ukraine of July 17, 1997 No 469/97 - VR] (1997). Bulletin of the Verkhovna Rada of Ukraine, 39, 261.

Reganold, J. P., \& Wachter J. M. (2016). Organic agriculture in the twenty-first century. Nat. Plants, vol. 2, p. 15221 .

Shpykuliak, O., \& Bilokinna, I. (2019). "Green" cooperatives in the formation of an institutional mechanism of thrdevelopment of alternative power engineering in the agrarian sector of the economy. Baltic Journal of Economic Studies, vol. 5(2), pp. 249-255. doi: 10.30525/2256-0742/2019-5-2-249-255

Trewavas, A. (2001). Urban myths of organic farming. Nature, no. 410, p. 409-410.

Ukrainian Agribusiness: Infographic Report 2019/2020. Retrieved December 15, 2020 from: https://agribusinessinukraine.com/get_file/id/infographicsukra inianagro 1920-en.pdf

Vnutrishnii rynok orhanichnoi produktsii Ukrainy, eksport ta import za 2019 rik [Domestic market of organic products of Ukraine, exports and imports in 2019]. Retrieved November 29, 2020 from: https://agropolit.com/infographics/view/95

Zhelibo, E. P., Hatska, L. P., \& Murovana, T. O. (2020). Perspektyvy rozvytku ekolohichnoho pidpryiemnytstva v Ukraini [Prospects of the development of eco-friendly entrepreneurship in Ukraine]. Efektyvna ekonomika [Efficient Economy], vol. 3. doi: 10.32702/2307-2105-2020.3.1. Retrieved December 1, 2020 from: http://www.economy.nayka.com.ua/?op=1\&z=7692 